\title{
World Christianity: Contours of an Approach
}

\author{
Martha Frederiks
}

\section{Introduction}

Over the past years, I have been teaching an introductory course on Christian history. During the weekly seminars the students read a selection of primary sources. One of the seminar sessions is dedicated to the 'Church of the East', during which we do a parallel reading of the text of the Nestorian monument, commemorating the 15oth anniversary of the 'luminous religion' in China (781) and the dialogue between the Abbasid caliph al-Mahdi and Nestorian Patriarch Timothy I in Baghdad (c. 780). Both materials originate from the same period and church tradition, but where the Nestorian monument uses Buddhist and Daoist notions to express Christianity, the Baghdadi dialogue engages Islam as its main conversation partner (Horne 1917: 381-392; Ji 2007: 24-81; Mingana 2009). Students are often astonished to discover that these texts, which are so dissimilar in genre, locality, and context, are connected through the person of Timothy I, who, while resident in Baghdad, was also the patriarch of the Nestorian churches in China when the monument was erected. Philip Jenkins calls him "arguably the most significant Christian spiritual leader of his day, much more influential than the Western pope, in Rome" (Jenkins 2008: 6).

Timothy's patriarchate was vast, with bishops in present-day Syria, Armenia, Yemen, Afghanistan, Azerbaijan, India, and China (Irvin and Sunquist 2001: 284-287). Yet however impressive the spatial extent of Timothy's ecclesial responsibilities, in the class we remind ourselves that there was more to the Christian story in the latter decades of the eighth century than the Church of the East. We recall, for example, that around the same time, somewhat further to the west, Empress Irene was taking measures to end the first period of Byzantine iconoclasm, itself a side-effect of the advance of Islam (Crone 2017: 361-397). Or that even further west on the Iberian Peninsula a member of the Umayyad dynasty had established the emirate of Cordoba and was commissioning the construction of the illustrious Mezquita de Cordoba on the site of a former Visigoth church (Hillenbrand 1994:113-114). Towards the north, Charlemagne was on the warpath, simultaneously submitting and Christianizing neighbouring Saxons and Lombards to realize his ambition to 
reinstate the Western Roman Empire and become a 'new Constantine' (Riche 1993: 117-125; Sypeck 2006).

We usually end our mental journeys 'at home', recollecting what was happening in our own context at the time. During the seminar on the Church of the East, for example, we recalled that during the late eighth century substantial parts of what later became the Netherlands were still mission territory. And we discovered that it may well have been the fortuitous meeting between Charlemagne and Alcuin of York in 781 and Alcuin's emphasis on Christianisation through persuasion rather than force, which eventually produced one of the oldest Christian vernacular texts of our area-the Heliand, a Saxon gospel harmony (Murphy 1995; Haug 1997: 27-30).

During the course, we consistently repeat the exercise of reading primary sources and recalling their context as well as events or developments (secular as well as religious) relevant to Christian history that occurred in other parts of the world at approximately the same time. Gradually, the students begin to discern a web of connectivities that links the Council of Toledo (589) with the Great Schism (1054), and the Fifth Crusade (1213-1221) with the fall of Dongola (1276) and the subsequent demise of Nubian Christianity. Also, after a number of weeks it begins to dawn on the students that there is not one story to tell about the history of Christianity, but that there are manifold narratives about a multiplicity of Christianities that are intricately entangled through webs of connectivities.

This prefatory anecdote introduces some of the features of what I call a 'World Christianity approach'. Rather than considering World Christianity a subject matter or a field of studies (Kollman 2014: 166), I conceptualize World Christianity to be an approach to study Christian tradition(s), entailing a number of methodological and theoretical perspectives. The vignette highlights several of those perspectives: the conceptualization of Christianity as an inherently plural, cumulative tradition (Smith 1964: 141) with multiple and variable centres of authority, influence, and power that shape(d) the tradition(s) throughout its history/ies; the multifaceted translocal connectivities between these Christianities; discernment and recognition of the entanglements of the Christian tradition(s) with political, economic, social, and cultural contexts as well as of Christian and other faith traditions and the subsequent range of Christianities this has produced; the importance of synchronic and diachronic studies of Christianity to uncover aforesaid entanglements and connectivities, to mention just a few.

In this chapter I will sketch the contours of such a 'World Christianity approach'. I use the word 'contours' advisedly because this approach is still very much 'in the making' and will benefit from further academic engagement. 
Mindful of the importance of situating myself as a researcher, I locate myself as an academic working in a religious studies department at a secular university in the Netherlands (Utrecht University) who studies Christianity from a religious studies perspective with a partiality to historical- and anthropological methods. My personal- and academic biography so far has resulted in an academic focus on the Christian tradition(s) in sub-Saharan Africa and on Christian-Muslim relations. Hence, many of the examples I cite and the academic debates with which I interact, are related to these areas of expertise. This is in no way intended to disavow the significance of other regions, examples, or debates. ${ }^{1}$

I will begin this contribution by briefly recapitulating the genealogy of the concept World Christianity and by situating the prevalent conceptualizations in current academic discussions. This is followed by an exploration of the rationale to opt for a World Christianity approach, rather than to consider World Christianity a subject matter or a field of study. Lastly, I will dot lines to demarcate the contours of such a World Christianity approach.

\section{World Christianity: The Career of a Concept}

The term 'World Christianity' is in vogue. Titles which feature World Christianity seem to proliferate, be they introductions to World Christianity, histories of World Christianity, perspectives in World Christianity, the role of theology or mission in World Christianity or readers in World Christianity. ${ }^{2}$ Also the nomenclature of academic chairs, journals and book series seems affected by what Paul Kollman (2014) has called the "world-Christian turn", with World Christianity rapidly replacing words such as missiology, 'non-Western' or 'Southern' Christianities, ecumenism or church history.

The notion World Christianity seems to exercise a compelling attraction to a wide-ranging audience. But as Peter Phan (2012: 172) has eloquently

1 For a theological take on a World Christianity approach see Nagy 2017.

2 The following brief bibliography, which is by no means comprehensive, can serve as an illustration: Introductions to World Christianity: Cooper 2016; Sanneh and McClymond 2016; Farhadian 2012. Histories of World Christianity: Irvin 2017; Daughrity and Athyal 2016; Shenk 2002; Sanneh 2008; Davies and Conway 2008; Irvin and Sunquist 2001, 2012; Ward and Stanley 200o. Perspectives in World Christianity: Cabrita, Maxwell and Wild-Wood 2017; Tan and Tran 2016; Burrows, Gornik and McLean 2011. The role of theology in World Christianity: Ogbonnaya 2017; Friedli 2010; Tennent 2007. Mission in World Christianity: Danielson 2017; Gallagher and Hertig 2009. Readers in World Christianity: Davies and Conway 2008; Coakley and Sterk 2006; Thomas 1995 . 
pointed out, "[p]opularity (...) does not always mean conceptual clarity and consistency." Various scholars have endeavoured to shed light on the multiple conceptualizations of World Christianity (Cabrita and Maxwell 2017: 5-30; Kollman 2014: 164-177; Thangaraj 2011: 11-13). Dana Robert (2011:149-151) traces the genealogy of World Christianity to the first half of 2oth century when the concept was coined in relation to mission and ecumenism by people like Francis John McConnell, Kenneth Scott Latourette, and later also Henry van Dusen. Where for Latourette 'World Christianity' represented the manifold ways in which the Christian tradition transformed and was transformed by multiple contexts, for Van Dusen World Christianity signified his strongly Protestant-based and European-centred expectation of an imminent Christian unity. Thus, according to Robert, in Van Dusen's work, the notion of 'World Christianity' was inextricably linked to the ecumenical élan and optimism of the 1940s and 1950s and lacked the dimension of "multicultural and ecclesial diversity" that Latourette and later conceptualizations considered critical. The concept gained new currency in the late 1980s, when academics like Andrew Walls and the late Lamin Sanneh recalibrated the term and conceptualized it as "Christianity as a non-Western religion with multiple local manifestations" (Robert 2011: 152) or in the words of Sanneh (2003: 22) as "a wide variety of original, indigenous expressions that do not necessarily share the Western Enlightenment frame." Where for Walls World Christianity signals a historiographic project, for Sanneh World Christianity is a constitutive concept in a postcolonial project (Frederiks 2019; Ngong 2020).

As a discursive concept this conceptualization of World Christianity is embedded in theories on the translatability and inculturation of the gospel (Sanneh 1989; Walls 1982, 1990) with a strong emphasis on the vitality and growth of 'Southern Christianity', most clearly expressed through the popular phrase that the 'center of gravity of Christianity is moving South'. The postulated but frequently implicit background to this conceptualization of World Christianity seems to be a representation of European Christianity as a tale of secularisation and decline. Against this context, the construct 'World Christianity' seems to function as a discursive reassurance that due to the "meteoric rise of non-Western Christianity" (both in loci and it in its migration settings) there is hope for the Christian faith after all (Akinade 2010: 5; Jenkins 2010: 15; Frederiks 2019). This is most explicitly articulated by the late Kwame Bediako in his contribution to the volume Understanding World Christianity, honouring Andrew Walls:

Thus, the present shifts in the center of gravity may have secured for Christianity a future that would otherwise be precarious in the 
secularized cultural environment of the modern West. It has given the faith a new lease on life in the predominantly religious worlds of Africa, Latin America, the Pacific and parts of Asia.

Bediako 2011: 246

It is this late 198 os conceptualization of World Christianity, with its focus on the vitality and multiple manifestations of the Christian tradition in Africa, Asia, Latin America, and Oceania that has become dominant. ${ }^{3}$ This conceptualization of 'world' in World Christianity as an abbreviation for originating from Africa, Asia, Latin America, and the Pacific, has striking parallels with notions such as World Cinema, World Music, and World Literature, which, in the words of Stephanie Dennison and Song Hwee Lim (2006:1) "are categories created in the Western world to refer to cultural products and practices that are mainly non-Western". 4

Several academics such as Namsoon Kang (2010: 33) and Sathianathan Clarke (2014: 195) have observed that discourses that adhere to this conceptualization of World Christianity often tend towards triumphalism and favour certain aspects of Christianity over others. The discourses seem to stress the demographic robustness and vitality of Christianity as well as its multiple local varieties, often supported by references to missiometric exercises which highlight the continued growth of Christianity. These discourses mainly seem to focus on continuities, vibrancy, and advance, rather than on discontinuities, ruptures, and decline. They also seem to have what Cabrita and Maxwell have called "a theological predisposition towards incarnational and translatability features of Christianity" and "a fetishistic commitment to regional particularity" but pay little attention to globalizing and integrative forces within the Christian tradition (Cabrita and Maxwell 2017: 21-22).

Subsequent academic debates have resulted in some modifications to the conceptualization of World Christianity sketched above. First of all, parallel to other academic disciplines, the stipulation of the qualifier 'world' in concepts like World Christianity, World Music or World Cinema as referencing solely the

3 This conceptualization seems particular popular among scholars in North America and academics connected to the Yale-Edinburgh group, a network initiated by Andrew Walls and Lamin Sanneh in the early 199os. Cabrita and Maxwell, who situate the emergence of the concept 'in a particular theological and political milieu of postcolonial anxiety' and consider it in part to be 'the product of missionaries and missiologists' postcolonial guilt', also point to the popularisation of the concept through the Currents in World Christianity Project funded by the Pew Charitable Trust (Cabrita and Maxwell 2017: 4, 12, 14). While not referenced by Cabrita and Maxwell, this once more points to the influence of Sanneh in promoting the concept; between 1990-200o he served a consultant for the Pew Charitable Trusts https:// divinity.yale.edu/sites/default/files/user-cv-uploads/lsanneh.pdf.

4 Dorottya Nagy in this volume critically examines the notion 'World' in World Christianity, discussing 'worldling' trends within the Humanities. 
non-Western world has been challenged and a case has been made to construe 'world' as 'world-wide' or pertaining to the whole of humanity (Phan 2012: 175; D'haen, Domíngez and Rosendahl Thomson 2013: x-xi; Nagib 2013: 30-37). Scholars like Thomas Thangaraj, Charles Farhadian, Kirsteen and Sebastian Kim as well as David Barrett in the World Christian Encyclopedia are examples of scholars who use the notion World Christianity to signify the geographic span of Christianity, indicating that Christianity has adherents worldwide. In this conceptualization 'World Christianity' includes the 'West' (Thangaraj 2011: 11-12; Farhadian 2012: 1; Kim and Kim 2008, 2016: ix). Others however refer to Christianity's dispersal across the globe by means of the concept 'Global Christianity' (e.g. Pew Forum; Escobar 2013; Johnson and Ross 2009; Robbins and Engelke 2010). And to underscore the at times bewildering muddle of terminology: Lamin Sanneh (2003: 22) uses the concept Global Christianity for "the faithful replication of Christian forms and patterns developed in Europe".

Secondly, academic debate has resulted in a corrective to the initial concentration on the contemporary in the conceptualization of World Christianity. Suggestions to also incorporate the historical dimensions have met with unequivocal acclamation and consensus, though the main body of research continues to focus on developments from the 19th century onwards (Irvin 2016:4; Kim and Kim 2008, 2016; Farhadian 2012).

Paul Kollman, in his endeavours to help clarify the manifold conceptualizations of World Christianity, has pointed out that the term World Christianity is not only used for a phenomenon but also for an emerging field of studies (Kollman 2014: 166). Dale Irvin and Klaus Koschorke can be considered the pioneers and most active promoters of the conceptualization of World Christianity as an emerging academic field. In 2008 Irvin, in his positioning article in The Journal of World Christianity describes 'World Christianity' as:

an emerging field that investigates and seeks to understand Christian communities, faith, and practice as they are found on six continents, expressed in diverse ecclesial traditions, and informed by the multitude of historical and cultural experiences ... It is concerned with both the diversity of local or indigenous expressions of Christian life and faith throughout the world, and the variety of ways these interact with one another critically and constructively across time and space. It is particularly concerned with under-represented and marginalized communities of faith, resulting in a greater degree of attention being paid to Asian, African, and Latin American experiences; the experience of marginalized communities within the North Atlantic world; and the experiences of women throughout the world. 
Both Irvin and Koschorke emphasize in their work that the field of World Christianity encompasses Christian expressions in present and past (therewith distinguishing it from for example the anthropology of Christianity ${ }^{5}$ which has a predominant focus on modern period; see e.g. Robbins 2014) and Christianity as practised on six continents, therewith explicitly including the North Atlantic hemisphere in the field of World Christianity, though Koschorke's work seems partial to "außereuropäischen Christentumsgeschichte" (Hermann and Burlacioiu 2016: 9). Also characteristic for both scholars is their dual focus on local particularities and translocal connectivities. Both also emphasize that the history of Christianity is entangled with wider regional- and world histories and interacts with a broad palette of cultural experiences.

Where Irvin foregrounds Christian expressions of the underrepresented and marginalized, reminiscent of a liberation theology approach and its 'preferential option for the poor', Koschorke has underscored the polycentric structures of World Christianity (Koschorke and Hermann 2014). While not conceptualized as 'World Christianity', there are striking parallels between Koschorke's plea for "veränderte Landkarten" and "polyzentrische Strukturen" and Justo González' insightful The Changing Shape of Church History, which argues the necessity of transforming the cartography and topography in church history and the need for 'polycentric' maps (González 2002: 1-32).

\section{3}

\section{Why an Approach?}

Considering the amount of energy spent on the conceptualization and exploration of 'World Christianity' both as a subject matter and as a field, the question seems justified: why a proposal to conceive World Christianity as an approach?6 I merely highlight three reasons:

Firstly, current attention for World Christianity (both as a subject matter and as a field) seems informed by a fascination for the numerical strength and vibrancy of Christianity (and often its more exotic expressions) with a predilection for the contemporary period, highlighting some developments in the Christian tradition, while disregarding others. Examples are usually drawn from Anglophone Africa, Latin American Pentecostalism, and to a lesser extent from Asia (e.g. China and Korea). As Dyron Daughrity (2013) has pointed out, Orthodoxy (Eastern as well as Oriental) seems absent from the research

5 The anthropology of Christianity is also distinct in its explicit attention for discontinuity, rupture and change (Robbins 2014).

6 For a rationale why not to discard the term all together see Nagy in this volume. 
agenda; also, attention for other historic 'mainline' churches (e.g. Presbyterian, Methodist or Roman Catholic) in the post-colonial era is limited. Some rhetoric elements are reiterated again and again, such as the creativity and vitality of Africa's 'new' Christianity, China's growth (Nagy 2010) or the vibrancy of migrant Christian communities in Europe, most notably The Embassy of the Blessed Kingdom of God in Kiev. ${ }^{7}$ Features of contemporary Christianity where vibrancy and numerical strength are less obvious, such as Christian minority churches in the Sahel, or North Africa, migrant communities in the Gulf or the continued role of state churches in Europe receive far less attention.

This lopsided representation of the Christian tradition and its unvoiced postulation that the significance of Christian communities is somehow linked to numerical strength is problematic. Furthermore, the tacit conjecture of much of the literature that emphasizes the growth of Christianity in 'the South' seems to be that the so-called 'shift of the center of gravity' also signifies a change in the power dynamics within Christianity worldwide. But as Tinyiko Maluleke has observed, while "in terms of numbers and dynamism the Christian center of gravity has indeed shifted", the "wealthiest adherents and institutions reside in the North" and therefore "the shift in the Christian center of gravity from North to South has not been able to displace the dominance of the North ..." (Maluleke 2016: 67-68). Current World Christianity research rarely seems to interrogate such presuppositions or scrutinize power dynamics within Christianity worldwide. ${ }^{8}$

Secondly, as delineated earlier and as Nagy (2017:144-145) has recently also detailed, current conceptualizations in the study of Christianity worldwide continue to be problematic. Both Irvin (2016: 15-16) and Nagy (2017: 146) have

7 Chandra Mallampalli (2017: 163-164) has flagged that the main architects of current conceptualizations of World Christianity were scholars in the study of African Christianity and has queried the aptness of some of its key features (e.g. translatability, cultural continuity and indigenous agency) for South East Asia and in particular India.

8 With the exception of the Constantine era and the colonial period-and possibly the contemporary struggle for power within the Anglican Communion-, there has been relatively little attention for the question how power dynamics have affected Christianity's manifestations, terminology, and conceptualizations in a given period and/or context. How have money flows, Jesus films, cheap American book publications, scholarships, access to internet and social media, military supremacy, commercial concessions, political domination or constructions of race, gender, caste, ethnicity etc. affected local expressions of Christianity as well as the relationships between the various local communities. Who claims to speak for 'Christianity' and with what aim? What allegiances, dependencies, and agendas are forged and promoted through aid programmes, ecumenical bodies, fraternal workers, remittances, political constellations or academic institutions and discourses in past and present? Who participates in the processes of fashioning, defining, transforming, and representing both local manifestations and translocal connectivities and who is excluded and why? 
flagged the equivocality of the concept 'the West'. Where Irvin has highlighted how the geographic locality of 'the West' shifts over time, Nagy has critiqued the postulated but problematic inclusion of Central and Eastern Europe in 'the West' and 'Europe'. Conceptualizations such as the 'West' and the 'South' are strongly informed by a specific type of colonial experience and may lead to an oversight of areas or Christian communities with different histories, as Daughrity's 'Ignoring the East' (2013) evidences. These examples also illustrate that any construct that attempts to equate discursive concepts with geographical locations, eventually runs into problems, as is for example evidenced by Irvin's need to reference "marginalized communities in the North Atlantic world" in his delineation of World Christianity. Paul Freston (2010) has also eloquently demonstrated this in his deconstruction of the popular notion 'reverse mission'.

Thirdly, and closely linked to the previous observations, as Arun Jones (2014), Nagy (this volume) and others have argued, much academic reflection on the study of Christianity worldwide continues to work along bipolar lines of thinking, that find their origin in the colonial period, continually producing and reproducing binaries such as 'missionary' versus 'indigenous', 'the West' versus 'the Rest', 'North' versus 'South. ${ }^{9}$ Critical interrogation of such binaries by no means intends to contest that Western colonialism was incisive in local histories in multiple ways and requires scholarly investigation. Nor does it intend to disavow that in numerous areas the first encounter with the Christian faith occurred during the period of Western colonialism, leading to a messy imbroglio of Christianity and colonialism. However, to make this colonial experience, an intrinsic part of the conceptual framework for the study of Christianity throughout its two-thousand-year history, does not merely once again foreground North Atlantic hegemonic power, but also does not do justice to nor is representative of the diverse power dynamics of Christianity's long and heterogeneous history. Moreover, academic concepts or methods that consciously or unconsciously take their point of departure in the-often unvoiced-assumption that Christianity in Ghana has more in common with Christianity in Indonesia or Argentina than with Christianity in the Netherlands or the United Kingdom, as for example terms such as 'Christianities from the global/majority South' seem to presume, in my view retain orientalist structures of 'othering' and need to be exposed and dismantled.

9 The presupposition of Irvin's expression "marginalized communities in the North Atlantic world" is that what distinguishes the 'rest of the world' from 'the North Atlantic' is the experience of marginalization. Likewise, Koschorke's use of terms like 'South-South' connections, or 'North-South' interactions reproduce such binaries (Koschorke 2016: 42). 
Conscious of all these conceptual and terminological challenges and pitfalls, Dorottya Nagy and I propose to invoke the term 'World Christianity' merely to indicate a particular approach to studying Christianity/ies. As Phan (2012: 172) and Ariarajah (this volume) have argued, the term 'Christianity' continues to evoke connotations of Christianity's "Western face". A World Christianity approach concurrently acknowledges and addresses this. Recognising Christianity's inherently plural character, ${ }^{10}$ it entails the conscious and consistent endeavour to study particular Christian communities, beliefs, or practices in the light of and in relation to Christianity's wider (hi)story, mindful of integrative and globalizing forces as well as of its multiple 'centers', trajectories, and agents, aware that Christianity's manifestations always shape and are shaped by broader political, socio-economic and religious developments, and cognizant of the diversity of beliefs and practices this has produced across time and space. Where Nagy opts for a theological take on this approach (Nagy 2017), mine is a religious studies perspective, meaning that I refrain from normative claims as to what constitute 'faithful' interpretations of Christianity. In the remainder of this chapter I want to sketch how I operationalize such a 'World Christianity' approach from a religious studies perspective, stressing once more that this is work in progress.

\section{$4 \quad$ Contours of an Approach}

\subsection{Critical Inquiry into Trajectories of Knowledge Production}

A key feature of a World Christianity approach as I envisage it consists of a critical inquiry into the trajectories of knowledge production and construction as well as into the genealogies of key analytic concepts and theories in the study of Christianity. Rather than naively and guilelessly using past hypotheses, terms, theories, and data-sets, we need to critically examine the metadata and meta-information of the research we utilize, aware of the context in which they were formulated and cognizant that neither "global awareness" (Nagy 2017: 144) nor attention for commensurate representation of academic actors have been defining characteristics of past scholarly endeavours. Similarly, as researchers we do not merely need to work on producing materials from more

10 While a World Christianity approach acknowledges Christianity's inherently plural nature, it also acknowledges the myriad of translocal connectivities that interconnect Christianity's multiple 'centers' as well as integrative forces within Christianity worldwide. Acknowledging both Christianity's centrifugal and centripetal dynamics I have opted for the continued use of the concept 'Christianity' rather than Christianities, which mainly highlights Christian particularities. 
inclusive perspectives, but also critically need to assess our own processes of knowledge production in order to detect biases and blind spots.

Therefore, a key feature of a World Christianity approach as I envisage it, is to critically interrogate past and present trajectories of knowledge production and the inherent mechanisms of exclusion and marginalization, mindful of the fact that there is disparity between researchers, that textual sources seem to dominate the knowledge production of Christianity, and sensitive to the fact that the production, conservation, and examination of texts during extensive periods of Christian history was the privilege of a small elite and hence not all voices are equally represented in past sources and current debates. (Farhadian 2012: 2-3).

Aim of this investigation is to create an awareness of how past and present trajectories of knowledge production and construction have shaped and continue shape our perceptions and conceptualizations of the Christian tradition(s). It is for example common knowledge that much of the past research on Christianity has worked with a Eurocentric perspective. Andrew Walls (2000: 107) once pithily called church history as taught until very recently, a "glorified form of European clan history". This eurocentrism is amongst other things expressed in the classic division of Christianity's history worldwide between church- and mission history. But, as Enrique Dussel (1967) has repeatedly stated, it is also exemplified in the way in which pivotal moments in Europe's history with Christianity still seem to determine the periodization of the history of Christianity worldwide." González (2002: 11-12) has evocatively pressed this point with his example that May 261521 was the day that the Edict of Worms was issued against Luther as well as the day that Hernán Cortés was laying siege to the imperial city of Tenochtitlán, stating that "many would agree that the jury is still out as to which of those two events will eventually prove to be more important for the history of the church at large." Thus, there is not merely a need to rewrite the history of Christianity from a wider, more inclusive, multi-centred perspective but it is also vital to critically assess the tools (e.g. concepts, theories, and periodization) which are employed in this endeavour. In the remainder of this paragraph I would like to illustrate this by briefly reflecting on two pivotal instruments in the process of knowledge production: researchers and sources.

Over the past decades there has been a growing awareness of the interplay between social location and academia. Bourdieu for example has pointed to the correlation between cultural, linguistic, and economic capital and

11 For a discussion of Dussel's critique of prevalent systems of periodization, see Raimundo Barreto, this volume. 
academic achievements. Nowadays, academics increasingly acknowledge that the academic world is not the level playing field it was imagined to be and that cultural, linguistic, and economic capital is a prerequisite for accessing international academic networks and prestigious publication channels (Bourdieu 1986: 241-258; Paltridge, Starfield and Tardy 2016). The acknowledgement that opportunities and resources have been and still are unequally allotted around the world and that unimpeded access to sources, publication outlets, and academic networks still is the privilege of a small elite, has major repercussions for knowledge production, considering this privileged group has the power to dominate academic debates, set its agendas, serve as peer-reviewers, and through referencing only a limited group of peers can also reproduce and further enhance the mechanisms of exclusion. ${ }^{2}$

Working with a World Christianity approach not merely implies being mindful of these mechanisms in past and present. In cognizance of postcolonial critiques of the production of knowledge about but without the 'other' (Kwok 2005: 3) as well as feminist theory stressing the importance of locating oneself in relation to knowledge production (Gottfried 2016: $5^{-7}$ ), it represents a proactive, conscientious effort to intellectually engage with (the work of) a broad spectre of scholars and sources from around the world and a vigilance regarding possible lacuna, 'blind spots' or biases in the work of previous generations as well as peers.

Also, sources require critical inquiry. Nowadays, most researchers are aware that Christianity's written history has chiefly been based on sources that were produced by a select elite and that much of the secondary literature takes a Eurocentric perspective (González 2002: 17-32). In response, numerous efforts have been (and are being) undertaken to recover the voices of hitherto underrepresented groups such as women, common people, indigenous agents or colonial subjects, at times supplementing archival materials with oral history or other sources (see e.g. Brock 2011; Grimshaw and May 2010; Phiri, Govinden and Nadar 2002; Soga and Williams 1983; Maretu 1983). Emma Wild-Wood (this volume) discusses strategies to critically interact with missionary sources (e.g. triangulation of sources) to trace indigenous voices, while Joseph Lee and Christie Chow (this volume) in their case-study on historiography of Christianity in China highlight the importance of moving beyond missionary and church sources to incorporate family archives, state documents etc. Irvin (2008:1-2) and González (2002: 26) have stressed the need of structurally incorporating these voices into the histories of Christianity. Irvin and Sunquist's History of the World Christian Movement $(2001,2012)$ and initiatives such as the 
Dictionary of African Christian Biography (www.dacb.org) and its derivative the Bibliographic Dictionary of Chinese Christianities (www.bdcconline.net) have begun to redress some of these issues. While recognizing that these processes need to start somewhere, it seems important to point out that much of this endeavor seems to privilege the recovery of Christian voices, thus making an implicit statement on the importance of other voices for understanding and writing Christianity's history.

While muted voices in historical sources have received considerable attention in the academia, the manner in which the density and accessibility of certain text- or archival corpuses seems to direct knowledge production has received far less reflection. To give an example: the quantity and accessibility (linguistic and otherwise) of archival materials from the colonial period in general and of the British Empire in particular have resulted in an overwhelming scholarly attention for this period. Though, as stated before, by no means denying that the colonial period was incisive in local histories in multiple ways and hence requires scholarly investigation, the disproportionate focus on the colonial period continues to further inscribe binary-thinking (the West and the Rest) as the overarching paradigm of all past cross-cultural encounter in academic literature and has tended to obscure and overshadow experiences from other periods, such as early modern period when relations between Africans (or Asians) and Europeans were more on par or the power balance was tilted in favor of Africans.

The predominant focus on the British materials also implies that theory on e.g. mission and colonialism is mainly based on experiences within the British Empire, which may or may not be representative for experiences with the Spanish, Portuguese, Danish, Dutch, French, Ottoman or Russian colonial empires. An analogous case is the manner in which theory on religion and migration has been chiefly developed on the basis of research on migrant Christian communities in the United States (Frederiks and Nagy 2016:2).

Another example of how documentation density and political clout have directed and shaped knowledge production is the portrayal of African enslavement. The vastness of the material on the transatlantic slave-trade conjoined with academic and political sway have produced a representation of the transatlantic slave-trade as the enslavement experience and has tended to eclipse other histories of enslavement, such as "the forced migration of black Africans into the Mediterranean world of Islam" and into Muslim societies in the Middle East and Asia, even though according to estimated guesses over the centuries nearly as many Africans were deported via Indian Oceanand trans-Saharan routes as via the trans-Atlantic routes (Frederiks 2016: 30; Hunwick 2002: ix; Segal 2002: 55-57). 
Similarly, accessibility of materials and academic bias have resulted in ample attention for the establishment of Portuguese Christianity on the Swahili coast. Yet while there is documented evidence that in the 16th century there were also Assyrian, Abyssinian- and possibly Indian Christian traders on the Swahili coast as far south as Kilwa (present-day Tanzania), this has received little to no scholarly consideration. This is all the more surprising considering that by the 16th century the dhow trade on the Swahili coast was already centuries old and it can therefore be inferred that the Swahili coast in all likelihood had been in been contact with Christians long before the documented evidence of the 16th century (Frederiks 2016: 35-36). Part of the reason for this inattentiveness, is the near exclusive focus on textual materials in the study of Christianity (the period of Antiquity exempted). I concur with Daughrity (2013: 51) who, referencing the work of Patrick Manning, points to the need to supplement the analysis of texts with other sources, such as material culture, linguistic analysis, migration patterns, and archaeological excavation, thus widening the basis for knowledge production on Christianity's histories and underscoring that Christianity's new historiography needs to be an interdisciplinary project.

\subsection{A Cumulative Tradition with Multiple Centers of Influence, Authority, and Power}

A key feature of a World Christianity approach is the acknowledgement (and scientific implementation) of Christianity as an inherently plural and cumulative tradition with a multiplicity of formal and informal 'centers' of authority, influence and power that have produced its heterogeneity in past and present. ${ }^{13}$ Many 'World Christianity' scholars have belaboured this point. These 'centers' (or hubs) may represent official Christian structures such as the seats of ecclesiastical hierarchies, but could also be devotional sites (e.g. Lourdes, Guadeloupe) or localities invested with discursive power (e.g. turning points in Christian history such as Wittenberg or Azuza Street). In addition there are political and economic centers which interact on Christianity e.g. Istanbul during Ottoman times, colonial London or the World Bank in Washington. Christianity's 'centers' are not stable and may lose their influence or appeal over time, underscoring what Bediako (2011: 246) once wrote: "that both accession and recession belong within Christian religious history."

13 Peter Phan (2008: 194) has used the image of a rhizome or rootstock plant for the dispersion of Christianity. I have chosen to use 'center' rather than center (without ") to dissociate both myself and the term from the center-margin debates; I rather conceptualize 'center' as a hub. 
Klaus Koschorke (2011, 2014b) has popularized the idea of Christianity's multiple centers with the expression "the polycentric structures of World Christianity". I prefer to speak of a cumulative tradition with multiple 'centers' of influence, power, and authority as the word 'structure' evokes connotations of formalization and institutionalization that may or may not be applicable. In addition, the word 'polycentric' is yet another ambiguous, equivocal term. While initially mainly common in biology/mycology, political science, and social-geography, the last decades of the twentieth century saw the rise of the notion 'polycentrism' in Roman Catholic theology, where the word was re-conceptualized to refer to the bourgeoning multi-culturality in what had previously been conceived as a mono- or Eurocentric Roman Catholic Church (Schillebeeckx 1985: ix; Schreiter 1991: 23; Tiénou 1993: 248-249). The concept emerged against the background of the catholicity debate and was according to Harvey Cox the pivot in the debate between Cardinal Ratzinger and Leonardo Boff (Cox 1988: 13, 146). But where in Roman Catholic literature in the latter part of the twentieth century the term was mainly used for the recent, cultural diversity within one church, Koschorke's conceptualization of polycentricism refers to Christianity's past history as well as current developments, is applied to the whole of the Christian tradition and concerns multiple centers of power and hierarchy rather than 'mere' centers of cultural diversity.

González has observed that acknowledging Christianity's multiple centers and trajectories in past and present has two main consequences for writing of the history of Christianity; it heralds the discontinuation of the separation of church history and history of mission, and it refutes constructions of the history of Christianity that consider the European tale to be the lead narrative. He writes:

The result is frightening and exhilarating. (...) I must somehow listen to those voices from other centers and from the margins that speak from different perspectives and see a past that is not exactly the same as I have seen. In fact, I can no longer speak of a single past, for out of these many centers and many perspectives come many pasts.

González 2002: 17

The emphasis by Koschorke, González, and others on multiple 'centers' in Christian present as well as past, presents a valuable corrective to the hegemony of Eurocentric (or wide: North Atlantic) narrative of the past. As part of the rectification process, it would be worth investigating when and why this Eurocentric reading of Christianity's history began to dominate the literature, for there is ample evidence throughout the centuries that amongst the churches' hierarchy there lingered a sustained awareness that there were multiple 
'centers' of Christianity, as is evidenced by e.g. the travels of Rabban Bar Sauma and Giovanni da Montecorvino, the presence of Ethiopians at the Council of Florence or the quest for Prester John. History is equally clear however, that awareness did not necessarily imply recognition of the other, as is demonstrated e.g. by the Fourth Crusade against Constantinople, Portuguese attempts at Latinizing Ethiopian- and Kerala Christianity and American Protestant evangelization of Oriental Christianity to mention just a few examples.

What would a World Christianity approach to Christianity as a cumulative tradition with multiple 'centers' of authority, influence and power entail for studying and writing Christian history? A World Christianity approach as I envisage it acknowledges and studies these multiple, diverse, versatile 'centers' and the beliefs and practices they advance, and pays explicit attention to the fact that the history of World Christianity is not a story of a linear expansion, but a narrative of both advance and decline, a story of conflicts and tensions as well as of occasional consensus and compromises (Woodberry 2012: 259-261). It entails studying the multiple manifestations of Christianity on their own as well as in a comparative perspective, diachronically or synchronically, endeavouring to understand and interpret them in context as well as in the light of and in relation to Christianity's wider (hi)story. Comparative studies could either be conducted within the Christian tradition or between Christian- and other faith traditions, studying parallel responses to political, social or economic developments or analogue movements, practices or transformation of beliefs (Janson and Meyer 2016). ${ }^{14}$

Furthermore, I concur with Klaus Hock who, following scholars such as Andrew Walls and Wilbert Schenk, and with a reference to the work of Dipesh Chakrabarty, has stressed the necessity of "provincializing" the European history/ies of Christianity: a project to discard Eurocentric perspectives as normative and to move beyond approaches that portray World Christian history as an extension of Europe's history of Christianity (Hock 2014: 399). Irvin (2016: 12) writes:

Although Western forms of thinking have dominated the Christian experience these past five hundred years, they have not been the only way Christians have expressed their faith. Recovering the memory of those

14 There is already a substantial body of literature on the Judaism, Christianity, Islam nexus. Some study the interconnectedness of the three traditions while others for example study similarities and differences in Muslim treatment of Jewish and Christian communities in al-Andalus or the Ottoman Empire or early modern Christian parallel responses to Judaism and Islam or Muslims (Braude and Lewis 1982, Armour 2004, Lowney 2005). 
diversities and understanding their implication for theory, method and practice today is one of the fundamental tasks that the study of World Christianity has to undertake.

Following Irvin (2016: 13), González (2002: 17) and Sanianathan Clarke I envisage an approach that advocates "a study of Christianity from perspectives that are engendered from around the globe" and that refuses "to set up the universe of inquiry postulating 'an other"' (Clarke 2014: 194). As Irvin has argued, studying Christianity worldwide in past and present requires a multiplicity of models and theoretical productions. Such an approach entails a critical inquiry of periodizations, key-turning points, conceptual categories as well as a re-assessment of our analytical toolbox.

\subsection{Translocal Connectivities and Integrative Dynamics}

The prominence given to Christianity's multiple 'centers', trajectories, and distinct indigenous responses has raised concern for the lack of coherence and connectedness this seems to suggest. Scholars like Charles Farhadian (2012:2) and Hartmut Lehmann (2014: 378-379) have pointed out that there are also integrative forces at work within Christianity, referring, among others, to global networks ${ }^{15}$ (e.g. YMCA, WCC or Bible societies) and the role of translocal media. Lehmann has argued that attention for "polycentric structures" alone, captures only part of the dynamics within Christianity's story and has proposed to complement this with attentiveness for "multi-polar networks". In his more recent work also Koschorke has highlighted the relevance of translocal connectivities; this prevents, to use his imagery, Christianity's new historiography becoming a "book-binder synthesis", which merely staples together a set of regional histories (Koschorke 2014b: 23). Koschorke (2016:42) has coined the expressions "multidirectional transcontinental interactions" and "plurality of crosslinks" to complement the notion of "polycentric structures". He writes:

Unlike former missionary historiography this concept does not primarily deal with traditional North-South connections-focussing on Euro-American mission activities overseas-or with South-North relationships - which have recently been discusses in detail, for example,

15 Abigail Green and Vincent Viaene have underscored the importance of these networks and have coined the term 'religious internationals', defined as 'a cluster of voluntary transnational organizations and representations crystallizing around international issues, in which both "ordinary" believers and religious specialists could serve as protagonists' (Green and Viaene 2012:1). 
in the context of African immigration and 'reverse mission' endeavours in Europe. Rather, it points to the plurality of cross-links in the so-called global South that in a new way have to be taken into account.

And he continues, especially "early instances of these transcontinental links in the 'Global South' are critical to such a new historiography" (Koschorke 2014a: 178). While by no means denying the pertinence of research into un(der) explored connectivities between African, Asian, Latin American or Oceanic expressions of Christianity, historical research seems to indicate that realities on the ground were more complex than these neat divisions between 'North-South' and 'South-South' connectivities seem to suggest. In 19th century Africa for example, these so-called 'North-South' and 'South-South' connectivities regularly intersected: in the 1840s West Indian- and German missionaries cooperated under auspices of the Basel Mission in the evangelization of people in present-day Ghana, the 185 os saw a joint missionary venture between British and West Indian Anglicans in the Rio Pongas, while in the latter part of the 19th century Indian Spiritans worked alongside Spiritans from Western Europe in East Africa (Gibba 2011; Koren 1994; Dickson 1969: 124).

But even when the concept translocal connectivities is widened beyond to facile binaries and bipolarities to include connectivities between local expressions of Christianity worldwide, it may still fail to capture the full extent of connectedness within the worldwide Christian community in past and present. David Maxwell (2017: 50) has for example drawn attention to "mechanisms of homogenisation, such as ritual practices, texts and institutions, that created uniformity within denominations and stimulated a broader sense of a universal faith" while Joel Robbins (2017: 247) has flagged up how in rural Papua New Guinea Christians experience a sense of connectedness to a worldwide Christian community. Such dynamics of homogenisation, incorporation, and belonging also play a role in knitting together local manifestations of Christianity and in creating the imaginary of a 'world-wide Christian community' and as such form a useful addition to the concepts of translocal connectivities as lenses for discerning Christianity's integrative dynamics.

A World Christianity approach as I visualize it, studies Christianity's local manifestations and histories in past and present but also pays attention to the integrative dynamics and translocal connectivities that, intentionally or serendipitously, interconnect(ed) local 'centres' and expressions across the globe. These dynamics and connectivities can take manifold modes and forms (human, material or immaterial) and can for example comprise of human agents, translocal organizations, and networks (e.g. denominational, missionary, ecumenical, academic, activist, cultural, ethnic, NGOs), trade networks 
(e.g. the Silk Road or the transatlantic trade), ritual practice, material objects (e.g. the Jesus film, relics, the harmonium, lithographs of the Broad and Narrow Way), creeds, periodicals, and books (e.g. Bunyan's Pilgrim's Progress), music, dress-styles, social media, or remittances to name just a few. At times also political preoccupation and policies have unintentionally forged translocal connectivities between Christian communities; communist friendship ties for example, concretized in exchange- and scholarship programmes, have produced connectivities which now contribute to the diversification of the religious landscape in Europe's former communist countries, with Nigerians founding churches in the Czech Republic or Chinese establishing Christian communities in Hungary and Romania (Bargár 2016; Nagy 2009). And as Van Liere convincingly demonstrates elsewhere in this volume, connectivities and dynamics of incorporation can also be forged through discourse and can be construed by agents both from within and outside the Christian tradition(s).

In the study of translocal connectivities in World Christianity sofar, human agency has been the main nexus of analysis. ${ }^{16}$ Amongst these the Black Atlantic connectivities feature prominently in the literature, with studies highlighting the role played by Congolese and Angolan Christians in the 17th and 18th centuries in the establishment of the Christian communities in the Americas, the contributions of liberated Africans and Maroons in the spread of Christianity in West Africa in the 19th century, and the significance of Ethiopianism for the development of African Independent Churches (Hanciles 2014; Heywood and Thornton 2007).

More complex and multifaceted are connectivities such as those highlighted by Mercedes García-Arenal (1992: 39-55). García-Arenal has made a comparative study of Spanish perceptions and evangelization strategies of moriscos and Indians. In her work she demonstrates that strategies of evangelization and othering, developed in view of the morisos in $15^{\text {th }}$ and 16th century Spain shape Spanish missionary approaches towards indigenous peoples in the New World, but also that the experiences of evangelizing Indians in turn informed and shaped policies towards moriscos on the Iberian peninsula. Similarly, Claire Midgley (2000) demonstrates how the British campaign against sati was simultaneously used to legitimate colonial rule (Spivak's white men saving brown women from brown men) and to enhance political participation of women in the UK. The dynamic interchange between the various nodes of these translocal connectivities and its impact on Christianity's manifestations, beliefs, and practices as well as the manner in which these interactions

16 More recently also the impact of missionary periodicals has drawn scholarly attention. See e.g. Hermann 2014; Hermann, Koschorke, Burlacioiu and Mogase 2016. 
enhance or are instigated by a sense of belonging to a worldwide Christianity community merit further research.

\subsection{An Entangled World}

A World Christianity approach not only examines the interactions between and within Christianity's multiple manifestations, but also recognizes that Christian communities and their beliefs and practices in past and present, are part of an entangled world. Christianity's manifestations and transformations are enmeshed with and entrapped in social, economic, cultural, political, and historical realities as well as with other faith traditions. A World Christianity approach studies how Christianity's communities, movements, beliefs, and practices simultaneously fashion and are shaped by these entanglements.

Both church- and mission history have a long pedigree in situating and interpreting Christian manifestations, beliefs and practices in relation to their wider socio-economic, cultural, political and religious settings. There is an extensive scholarship on how Christian beliefs and practices have structured their environment (e.g. calendar, landscape, art, gender constructions, and ethics) as well as how Christian beliefs and practices in past and present have been moulded by their contexts (e.g. Tomkins 2005; Irvin and Sunquist 2001, 2012).

Studying Christianity as part of an entangled world implies studying the multiplicities and genealogies of causes and effects that enmesh Christian manifestations and practices with social, economic, cultural, political and historical realities as well as with other faith traditions. Sanneh's renowned study Translating the Message (1989) for instance exemplifies some of these multifaceted dynamics through the lens of Bible translation, expounding how language and imagery of Bible translations are shaped by their linguistic, religious, and cultural contexts, while also highlighting the impact of Bible translations on issues as diverse as the standardization of languages and the rise of African nationalist movements. Anna Johnston (2003) has taken missionary writings as a lens into the entanglements of the missionary movement and the colonial project. Drawing on insights from postcolonial studies, Johnston examines LMS missionary writings as sites of mutual imbrication and discloses the role of missionaries in the complex interplay between colony and metropolis. She argues that missionary representations of gender, domesticity, and sexuality changed both missionaries and the societies they came from, thus influencing British ideologies on race, class, and gender (Johnston 2003:3). Similarly, Patrick Harries and Marcus Tomalin have pointed to entanglements of the 19th century missionary with the development of science, such as entomology and botany (Harries 2012), and linguistics (Tomalin 2011) while studies on Pentecostalism have disclosed Pentecostalism's entanglements with capitalism and modernity 
and pointed to its impact on entrepreneurship, family life, and gender relations (Martin 2002; Soothill 2007). Each of these studies underscores Christianity's manifold and complex entanglements with social, economic, political, cultural and political issues and invites further investigation of new fields and deeper levels of imbrication and interconnectedness.

As Wesley Ariarajah argues elsewhere in this volume, correlations and entanglements of Christian- and other faith traditions merit explicit attention in a World Christianity approach. Local Christian manifestations and expressions are enmeshed with other faith traditions. The opening paragraph of this chapter referenced Daoist and Buddhist imagery on the Nestorian Stele. Contemporary belief in reincarnation or the practice of yoga and Zen meditation among Christians in the United States could also serve as illustrations of such entanglements (Gunther Brown 2013). Similarly, other faith traditions have also been transformed in the encounter with Christianity and Christian agents, as is evidenced by the development of Sufism as a result of interaction with, amongst others, Christian and Buddhist monastic traditions, by the Hindu renaissance in India as a result of the 19th century missionary encounter (Oddie 1999; Mallampalli 2003) or by Buddhism becoming a much more text-based tradition through a codification of an 'Ur-text' and standardization of key texts due to its encounter with Christianity (Woodberry 2012: 262). Some ten years ago, Welmoet Boender convincingly demonstrated that imams in Western Europe have begun to take on pastoral roles traditionally associated with Christian ministers (Boender 2007). These illustrations exemplify the multiple and multifaceted correlations across religious traditions in past and present, demonstrating that religious manifestations, beliefs, and practices continuously transform in mutual interaction; they also underscore how problematic conceptualizations of religious traditions as distinct entities are.

Recognizing and appreciating these entanglements, Wesley Ariarajah in this volume calls upon theologians to move beyond tacit observation and acknowledgment of such religious entanglements, challenging them to face the far-reaching implications for Christian theology/ies and Christian exclusivist claims this entails, while Raimundo Barreto makes a case for studying the history of Christianity as part of a wider history of religion project, thus making clear that also academic research contributes to the constant (re)negotiation of Christian beliefs and practices. ${ }^{17}$ 


\section{Concluding Remarks}

In this contribution I have endeavored to demonstrate that ambiguities, equivocality, and conceptual pitfalls continue to afflict current conceptualizations of World Christianity. As response to this I have proposed to use the term World Christianity for a particular approach to studying Christianity in past and present. Recognizing Christianity's inherently plural character, I have described a World Christianity approach as entailing an interdisciplinary, conscious and consistent endeavour to study particular Christian communities, beliefs, or practices in the light of and in relation to Christianity's wider (hi)story, aware that Christianity's manifestations always shape and are shaped by broader political, socio-economic, cultural, and religious developments, mindful of its multiple agents, 'centers', and trajectories as well as of its integrative dynamics and translocal connectivities, and cognizant of the diversity of beliefs and practices this has produced across time and space. In this contribution I have described the (initial) contours of such an approach by highlighting four features: a critical inquiry into trajectories of knowledge production and construction, the recognition and scientific implementation of Christianity as a plural, cumulative tradition with multiple 'centers' in past and present, the study of Christianity's integrative dynamics and translocal connectivities, and the exploration of Christianity's multifaceted entanglements in past and present with social, economic, cultural, political orders and realities as well as with other faith traditions.

\section{Bibliography}

Akinade, Akintunde E. (2010). 'Introduction. The Grandeur of Faith. Exploring World Christianity's Multiple Trajectories.' In Akintunde E. Akinade, ed. A New Day. Essays on World Christianity in Honor of Lamin Sanneh. New York: Peter Lang: 1-13.

Asante, Emmanuel (2007). Culture, Politics and Development. Ethical and Theological Reflections on the Ghana Experience, s.l., Ghana: Combert Impressions.

Armour, Rollin (2004). Islam, Christianity, and the West. A Troubled History. Maryknoll NY: Orbis Books.

Bargár, Pavol (2016). 'Nigerian-Initiated Pentecostal/Charismatic Churches in the Czech Republic. Active Missionary Force or a Cultural Ghetto.' In Martha Frederiks and Dorottya Nagy, eds. Religion, Migration, and Identity. Methodological and Theological Explorations. Leiden: Brill: 79-96.

Barrett, David B., George T. Kurian and Todd M. Johnson (2001). World Christian Encyclopedia. A Comparative Survey of Churches and Religions in the Modern World. Oxford: Oxford University Press (2nd edition). 
Bediako, Kwame (2011). 'The Emergence of World Christianity and the Remaking of Theology.' In William R. Burrows, William R., Mark R. Gornik and Janice A. McLean, eds. Understanding World Christianity. The Vision and Work of Andrew F. Walls. Maryknoll, NY: Orbis Books: 242-255.

Boender, Welmoet (2007). Imam in Nederland. Opvattingen over Zijn Religieuze Rol in de Samenleving. Amsterdam: Bakker.

Bourdieu, Pierre (1986). 'The Forms of Capital.' In John G. Richardson ed. Handbook of Theory and Research for the Sociology of Education. New York: Greenwood: 241-258. Braude, Benjamin and Bernard Lewis, eds. (1982). Christians and Jews in the Ottoman Empire. The Functioning of a Plural Society. New York: Holmes \& Meier Publishers.

Brock, Peggy (2011). The Many Voyages of Arthur Wellington Clah, a Tsimshian Man and the Pacific Northwest Coast. Vancouver: U BC Press.

Burrows, William R., Mark R. Gornik and Janice A. McLean, eds. (2011). Understanding World Christianity. The Vision and Work of Andrew F. Walls. Maryknoll, NY: Orbis Books.

Cabrita, Joel and David Maxwell (2017). 'Introduction. Relocating World Christianity.' In Joel Cabrita, David Maxwell and Emma Wild-Wood, eds. Relocating World Christianity. Interdisciplinary Studies in Universal and Local Expressions of the Christian Faith. Leiden: Brill: 1-44.

Chitando, Ezra (2010). 'Review of F. Becker and P.W. Geissler, eds. Aids and Religious Practice in Africa.' Exchange 39,2: 289-29o.

Clarke, Sathianathan (2014). 'World Christianity and Postcolonial Mission. A Path Forward for the 21st Century'. Theology Today 71,2: 192-206.

Coakley, John W. and Andrea Sterk (2006). Readings in World Christian History. Vol. 1 Earliest Christianity to 1453. Maryknoll NY: Orbis Books.

Cooper, Derrek (2016). Introduction to World Christian History. Downers Grove: InterVarsity Press.

Cox, Harvey G. (1988). The Silencing of Leonardo Boff. The Vatican and the Future of World Christianity. Oak Park, IL: Meyer-Stone.

Crone, Patricia (2017). 'Islam, Judeo-Christianity and Byzantine Iconoclasm.' In Michael Bonner, ed. Arab-Byzantine Relations in Early Islamic Times. New York: Routledge: $361-397$.

Danielson, Robert A., ed. (2017). Teaching Mission in an Age of World Christianity. Wilmore KY: First Fruits Press.

Daughrity, Dyron B. (2013). 'Ignoring the East. Correcting a Serious Flaw in World Christianity Scholarship.' In Afe Adogame and Shobana Shankar, eds. Religion on the Move! New Dynamics of Christian Expansion in a Globalizing World. Leiden: Brill: 41-59.

Daughrity, Dyron B. and Jesudas M. Athyal (2016). Understanding World Christianity. India. Minneapolis MN: Augsburg Fortress. 
Davies, Noel and Martin Conway (2008). World Christianity in the 2oth Century. London: scm Press.

Davies, Noel and Martin Conway, eds (2008). World Christianity in the 2oth Century. A Reader. London: scm Press.

Dennison, Stephanie and Song Hwee Lim (2006). 'Situating World Cinema as a Theoretical Problem.' In Stephanie Dennison and Song Hwee Lee, eds. Remapping World Cinema. Identity, Culture and Politics in Film. London: Wallflower Press: 1-15.

D'haen, Theo, César Domíngez and Mads Rosendahl Thomson (2013). 'Introduction.' In Theo D'haen, César Domíngez and Mads Rosendahl, eds. World Literature. A Reader. London: Routledge: X-XII.

Dickson, Kwamina B. (1969). A Historical Geography of Ghana. London: Cambridge University Press.

Dussel, Enrique (1967). Hipóteses para una História de la Iglesia en América Latina. Barcelona: Estela.

Escobar, Samuel (2013). A Time for Mission. A Challenge for Global Christianity. Carlisle: Langham Global Library.

Farhadian, Charles F., ed. (2012). Introduction to World Christianity. Malden MA: Wiley and Blackwell.

Frederiks, Martha T. (2016). 'Enforced Migration. An Indian Ocean Narrative.' In David Thomas et al. eds. Christian Muslim Relations. A Bibliographic History. Vol. 11 South and East Asia, Africa and the Americas (17th century). Leiden: Brill: 29-49.

Frederiks, Martha and Dorottya Nagy (2016). Religion, Migration, and Identity. Methodological and Theological Explorations. Leiden: Brill.

Frederiks, Martha T. (2019). "Microcosm" of the Global South. The Discursive Functionality of Migrant Christianity in World Christianity Discourses.' Exchange 48, 4: 313-333.

Freston, Paul (2010). 'Reverse Mission. A Discourse in Search of Reality.' Pentecostudies 9, 2:153-174.

Friedli, Richard, ed. (2010). Intercultural Perspectives and Prospects of World Christianity. Frankfurt am Main: Peter Lang Verlag.

Gallagher, Robert L. and Paul Hertog, eds (2009). Landmark Essays in Mission and World Christianity. Maryknoll NY: Orbis Books.

García-Arenal, Mercedes (1992). 'Moriscos and Indians. A Comparative Approach.' In: Geert Jan van Gelder and Ed de Moor, eds. The Middle East and Europe. Encounters and Exchanges. Amsterdam: Rodopi: 39-55.

Gibba, Bakary (2011). The West Indian Mission to West Africa. The Rio Pongas Mission, 1850-1963. Unpublished Ph.D. Thesis, University of Toronto.

González, Justo L. (2002). The Changing Shape of Church History. St. Louis, MO: The Chalice Press. 
Gottfried, Heidi (1996). 'Engaging Women's Communities. Dilemma's and Contradictions in Feminist Research.' In Heidi Gottfried, ed. Feminism and Social Change. Bridging Theory and Praxis. Champaign IL: University of Illinois Press: 1-22.

Green, Abigail and Vincent Viaene (2012). 'Introduction. Rethinking Religion and Globalization.' In Abigail Green and Vincent Viaene, eds. Religious Internationals in the Modern World. Globalization and Faith Communities since 1750. New York: Palgrave MacMillan: 1-18.

Grimshaw, Patricia and Andrew May, eds (2010). Missionaries, Indigenous Peoples and Cultural Exchange. Brighton: Sussex Academic Press.

Gunther Brown, Candy (2013). The Healing Gods. Complementary and Alternative Medicine in Christian America. Oxford: Oxford University.

Hanciles, Jehu J. (2014). 'The Black Atlantic and the Shaping of African Christianity, 1820-1920.' In Klaus Koschorke and Adrian Hermann, eds. Polycentric Structures of in the History of World Christianity. Wiesbaden: Harrassowitz: 29-5o.

Harries, Patrick (2012). 'Natural Science and Naturvölker. Missionary Entomology and Biology.' In Patrick Harries and David Maxwell, eds. The Spiritual in the Secular. Missionaries and Knowledge about Africa. Grand Rapids: Eerdmans Publishing: 30-71.

Haug, Walter (1997). Vernacular Literary Theory in the Middle Ages. The German Tradition, 800-1300, in its European Context, Cambridge: Cambridge University Press.

Hermann, Adrian and Ciprian Burlacioiu (2016). 'Introduction. Klaus Koschorke and the "Munich School" Perspective on the History of World Christianity.' The Journal of World Christianity 6,1: 4-27.

Hermann, Adrian, Klaus Koschorke, Ciprian Burlacioiu, and E. Phuti Mogase (2016). Discourses of Indigenous Christian Elites in Colonial Societies in Asia and Africa around 1900. A Documentary Sourcebook from Selected Journals. Harrassowitz: Wiesbaden.

Hermann, Adrian (2014). 'The Early Periodicals of the Iglesia Filipina Independiente (1903-1904) and the Emergence of a Transregional and Transcontinental Indigenous-Christian Public Sphere.' Philippine Studies. Historical and Ethnographic Viewpoints $62,3-4,549-565$.

Heywood, Linda and John K. Thornton (2007). Central Africans, Atlantic Creoles and the Foundation of the Americas, 1585-1660. New York: Cambridge University Press.

Hillenbrand, Robert (1994). "The Ornament of the World". Medieval Córdoba as Cultural Center.' In Salma K. Jayyusi and Manuela Marín, eds. The Legacy of Muslim Spain. Leiden: Brill: 112-135.

Hock, Klaus (2014). 'Transkulturelle Perspektiven und das Programm einer Polyzentrischen Christentumsgeschichte.' In Klaus Koschorke and Adrian Hermann, eds. Polycentric Structures of in the History of World Christianity. Wiesbaden: Harrassowitz: 399-408. 
Horne, Charles F., ed. (1917). The Sacred Books and Early Literature of the East. Vol. XII Medieval China, New York: Parke, Austin and Lipscomb.

Hunwick, John (2002). 'The Same but Different. Africans in Slavery in the Mediterranean Muslim World.' In John Hunwick and Eve M. Troutt Powell, eds. The African Diaspora in the Mediterranean Lands of Islam. Princeton NY: Markus Wiener Publishers: IX-XXIV.

Irvin, Dale T. (2008). 'World Christianity. An Introduction.' The Journal of World Christianity 1,1: 1-26.

Irvin, Dale T. (2016). 'What is World Christianity?' In Jonathan Y. Tan and Ahn Q. Tran, eds. World Christianity. Perspectives and Insights. Essays in Honor of Peter C. Phan. Maryknoll NY: Orbis Books: $3-27$.

Irvin, Dale T. (2017). The Protestant Reformation and World Christianity. Global Perspectives. Grand Rapids: Eerdmans.

Irvin, Dale T. and Scott W. Sunquist (2001). History of the World Christian Movement. Vol. 1: Earliest Christianity to 1453. Maryknoll: Orbis Books.

Irvin, Dale and Scott W. Sunquist (2012). History of the World Christian Movement. Vol. 2: Modern Christianity from 1454-18oo. Maryknoll: Orbis Books.

Janson, Marloes and Birgit Meyer (2016). 'Introduction. Towards a Framework for the Study of Christian-Muslim Encounters in Africa.' Africa 86,4: 615-619.

Jenkins, Philip (2008). The Lost History of Christianity. The Thousand-Year Golden Age of the Church in the Middle East, Africa and Asia-And How It Died. New York: HarperCollins.

Ji, Jingyi (2007). Encounters between Chinese Culture and Christianity. A Hermeneutical Perspective. Berlin: LIT Verlag.

Johnson, Todd M. and Kenneth Ross (2009). The Atlas of Global Christianity. 1910-2010. Edinburgh: Edinburgh University Press.

Johnston, Anna (2003). Missionary Writing and Empire, 1800-1860. Cambridge: Cambridge University Press.

Jones, Arun W. (2014). 'Scholarly Transgressions. (Re)writing the History of World Christianity.' Theology Today 71,2: 221-232.

Kang, Namsoon (2010). 'Whose/Which World in World Christianity. Towards World Christianity as Christianity of Worldly-Responsibility.' In Akintunde E. Akinade, ed. A New Day. Essays on World Christianity in Honor of Lamin Sanneh, New York: Peter Lang: 31-48.

Kim, Kirsteen and Sebastian Kim (2008), Christianity as a World Religion. An Introduction. London: Bloomsbury Academic [2nd revised edition in 2016]

Kollman, Paul (2014). 'Understanding the World-Christian Turn in the History of Christianity and Theology.' Theology Today 71,2: 164-177.

Koren, Henry J. (1994). Spiritan East Africa Memorial, 1863-1993. Bethel Park PA: Spiritus Press. 
Koschorke, Klaus (2011). 'Changing Maps of the History of Global Christianity.' In Katharina Kurter and Jens Holger Schjørring, eds. Europäisches und Globales Christentum. Herausforderungen und Transformationen im 20. Jahrhundert. Göttingen: Vanderhoeck \& Ruprecht: 273-293.

Koschorke, Klaus (2014a). 'New Maps of the History of World Christianity. Current Challenges and Future Perspectives.' Theology Today 71,2: 178-191.

Klaus Koschorke and Adrian Hermann, eds. (2014b) Polycentric Structures in the History of World Christianity/Polyzentrische Strukturen in der Geschichte des Weltchristentums. Wiesbaden: Harrassowitz.

Koschorke, Klaus (2016). 'Transcontinental Links, Enlarged Maps, and Polycentric Structures in the History of World Christianity.' The Journal of World Christianity 6,1: $28-56$.

Kwok, Pui-lan (2005). Postcolonial Imagination and Feminist Theology. Louisville: Westminister John Knox Press.

Lehmann, Harmut (2014). 'Polyzentrische Strukturen in der Geschichte des Weltchristentums als Forschungsprogramm.' In Klaus Koschorke \& Adrian Hermann, eds. Polycentric Structures in the History of World Christianity. Wiesbaden: Harrassowitz Verlag: $377-379$.

Lienemann, Wolfgang (2014). 'Die Christenheit in der Weltgesellschaft. Kommentar und Fragen zu einem Forschungsprogramm.' In Klaus Koschorke \& Adrian Hermann, eds. Polycentric Structures in the History of World Christianity. Wiesbaden: Harrassowitz Verlag: 385-393.

Lowney, Chris (2005). A Vanished World. Muslims, Christians, and Jews in Medieval Spain. Oxford: Oxford University Press.

Mallampalli, Chandra (2017). 'The Orientalist Framework of Christian Conversion in India. Three Venues of "Inducement" from Colonial Times to the Present.' In: Joel Cabrita, David Maxwell and Emma Wild-Wood, eds. Relocating World Christianity. Interdisciplinary Studies in Universal and Local Expressions of the Christian Faith. Leiden: Brill: $162-186$.

Mallampalli, Chandra (2003). 'British Missions and the Rise of Indian Nationalism 1880-19o8. In Andrew N. Porter, ed. The Imperial Horizons of British Protestant Missions, 1880-1914'. Grand Rapids: W.B. Eerdmans Publishers: 151-181.

Maluleke, Tinyiku S. (2000). 'The Quest for Muted Black Voices in History. Some Pertinent Issues in (South) African Mission Historiography.' Missionalia 28.1: 41-61.

Maluleke, Tinyiku S. (2016), 'Christian Mission in a World under the Grip of an Unholy Trinity. Inequality, Poverty and Unemployment.' In Mari-Anna Auvinen Pöntinen and Jonas A. Jørgensen, eds. Mission and Money. Christian Mission in the Context of Global Inequalities. Leiden: Brill: $63-84$.

Maretu (1983). Cannibals and Converts. Radical Change in the Cook Islands. Transl. and edited by Marjorie Tuainekore Crocombe. Suva: University of South Pacific. 
Martin, David (2002). Pentecostalism. The World Their Parish. Oxford. Blackwell.

Maxwell, David (2017). 'Historical Perspectives on Christianity Worldwide. Connections, Comparisons and Consciousness.' In Joel Cabrita, David Maxwell and Emma Wild-Wood, eds. Relocating World Christianity. Interdisciplinary Studies in Universal and Local Expressions of the Christian Faith. Leiden: Brill: 47-69.

Midgley, Clare (2000). 'Female Emancipation in an Imperial Frame. English Women and the Campaign against Sati (Widow-Burning) in India, 1813-30.' Women's History Review 9,1: 95-121.

Mingana, Alphonse (2009). The Apology of Timothy the Patriarch before the Caliph Mahdi. Piscataway, NJ: Gorgias Press.

Murphy, G. Ronald (1995). The Saxon Saviour. The Germanic Transformation of the Gospel in the Ninth-Century Heliand. Oxford: Oxford University Press.

Nagib, Lúcia (2013). 'Towards a Positive Definition of World Cinema.' In Theo D’haen, César Domíngez and Mads Rosendahl, eds. World Literature. A Reader. London: Routledge: $30-37$.

Nagy, Dorottya (2009). Migration and Theology. The Case of Chinese Christian Communities in Hungary and Romania in the Globalisation Context. Zoetermeer: Boekencentrum.

Nagy, Dorottya (2010). 'Where is China in World Christianity?' Diversities 12,1: $70-83$.

Nagy, Dorottya (2017). 'World Christianity as a Theological Approach. A Reflection from Central and Eastern Europe.' In Joel Cabrita, David Maxwell and Emma Wild-Wood, eds. Relocating World Christianity. Interdisciplinary Studies in Universal and Local Expressions of the Christian Faith. Leiden: Brill: 143-161.

Ngong, David T. (2020). 'Domination and Resistance. Lamin Sanneh, Eboussi Boulaga, and the Reinterpretation of Christianity in Africa.' Exchange 49,2: 93-109.

Oddie, Geoffrey A. (1999). Missionaries, Rebellion and Proto-Nationalism. James Long of Bengal 1814-87. Richmond, Surrey: Curzon.

Ogbonnaya, Joseph (2017). African Perspectives on Culture and World Christianity. Cambridge: Cambridge University Press.

Paltridge, Brian, Sue Starfield and Christine M. Tardy (2016). Ethnographic Perspectives on Academic Writing. Oxford: Oxford University Press.

Phan, Peter C. (2008). 'World Christianity and Christian Mission. Are They Compatible? Insights from the Asian Churches. International Bulletin of Missionary Research 32,4: 193-200.

Phan, Peter C. (2012), 'World Christianity. Its Implications for History, Religious Studies and Theology.' Horizons 39,2: 171-188.

Phan, Peter C. (2017). 'Doing Theology in World Christianities. Old Tasks, New Ways.' In Joel Cabrita, David Maxwell and Emma Wild-Wood, eds. Relocating World Christianity. Interdisciplinary Studies in Universal and Local Expressions of the Christian Faith. Leiden: Brill: 115-142. 
Phiri, Isabel A., Devarakshanam B. Govinden and Sarojini Nadar, (2002). Her-Stories. Hidden Histories of Women of Faith in Africa. Pietermaritzburg: Cluster Publications. Riche, Pierre (1993). The Carolingians. A Family who Forged Europe. Philadelphia, PA: University of Pennsylvania Press.

Robbins, Joel and Matthew Engelke (2010). 'Introduction. Global Christianity, Global Critique.' South Atlantic Quarterly 109,4: 623-631.

Robbins, Joel (2014). 'The Anthropology of Christianity. Unity, Diversity, New Directions.' Current Anthropology 55,10: 157-171.

Robbins, Joel (2017). 'Anthropological Perspectives on World Christianity.' In Joel Cabrita, David Maxwell and Emma Wild-Wood, eds. Relocating World Christianity. Interdisciplinary Studies in Universal and Local Expressions of the Christian Faith. Leiden: Brill: 238-257.

Robert, Dana L. (2011). 'Historiographic Foundations from Latourette and Van Dusen to Andrew F. Walls.' In William R. Burrows, Mark R. Gornik and Janice A. McLean, eds. Understanding World Christianity. The Vision and Work of Andrew F. Walls. Maryknoll, NY: Orbis Books: 141-154.

Sanneh, Lamin (1989). Translating the Message. The Missionary Impact on Culture. Maryknoll NY: Orbis Books.

Sanneh, Lamin (2003). Whose Religion is Christianity? The Gospel Beyond the West. Grand Rapids: Eerdmans.

Sanneh, Lamin (2008). Disciples of All Nations. Pillars of World Christianity. Oxford: Oxford University Press.

Sanneh, Lamin and Michael McClymond, eds (2016). The Wiley-Blackwell Companion to World Christianity. Madden MA: John Wiley and Sons Ltd.

Schillebeeckx, Edward (1985). 'Foreword.' In Robert J. Schreiter, Constructing Local Theologies. Maryknoll NY: Orbis Books: IX-X.

Schreiter, Robert J. (1991). 'Ethnicity and Nationality as Contexts for Religious Experience.' In Peter C. Phan, Ethnicity, Nationality and Religious Experience. Lanham: University of America Press: 9-28.

Segal, Ronald (2002). Islam's Black Slaves. The Other Diaspora. New York: Farrar, Straus and Giroux.

Shenk, Wilbert R. (2002). Enlarging the Story. Perspectives on Writing World Christian History. Eugene OR: Wipf and Stock Publishers.

Smith, William Cantwell (1964). The Meaning and End of Religion. New York: Mentor Books.

Soga, Tiyo (1983). The Journal and Selected Writings of the Reverend Tiyo Soga. Edited by Donovan Williams. Cape Town: Balkema.

Soothill, Jane (2007). Gender, Social Change and Spiritual Power. Charismatic Christianity in Ghana. Leiden: Brill. 
Sypeck, Jeff (2006). Becoming Charlemagne. Europe, Baghdad, and the Empires of A.D. 8oo. New York: HarperCollins Publishers.

Tan, Jonathan Y. and Ahn Q. Tran, eds (2016). World Christianity. Perspectives and Insights. Essays in Honor of Peter C. Phan. Maryknoll NY: Orbis Books.

Tennent, Timothy C. (2007). Theology in the Context of World Christianity. How the Global Church is Influencing the Way We Think About and Discuss Theology. Grand Rapids: Zondervan.

Thomas, Norman E. (1995), Classic Texts in Mission and World Christianity. Maryknoll NY: Orbis Books.

Tiénou, Tite (1993). 'Forming Indigenous Theologies.' In James M. Phillips and Robert T. Coote, eds. Towards the 21st Century in Christian Mission. Grand Rapids: Eerdmans Publishing: 245-252.

Thangaraj, M. Thomas (2011). 'An Overview. Asian and Oceanic Christianity in the Age of World Christianity.' In Heup Young Kim, Fumitaka Matsuoka and Anri Marimoto, eds. Asian and Oceanic Christianities in Conversation. Exploring Theological Identities at Home and in Diaspora, Amsterdam: Rodopi: 11-21.

Tomalin, Marcus (2011). “And He Knew Our Language”. Missionary Linguistics on the Pacific Northwest Coast, John Benjamins Publishing Company.

Tomkins, Stephen (2005). A Short History of Christianity. Oxford: Lion Hudsons.

Walls, Andrew F. (1982). 'The Gospel as Prisoner and Liberator of Culture.' Faith and Thought 1 \& 2: 39-52 [republished in Andrew F. Walls (1996). The Missionary Movement in Christian History. Studies in the Transmission of Faith. Edinburgh: T\&T Clark: $3^{-15}$.

Walls, Andrew F.(1990). 'The Translation Principle in Christian History.'In Philip C.Stine, ed. Bible Translation and the Spread of the Church. Leiden: Brill: 24-39.

Walls, Andrew F. (2000). 'Eusebius Tries Again. Reconceiving the Study of Christian History', International Bulletin of Mission Research 24,3: 105-111.

Ward, Kevin and Brian Stanley, eds (2000). The Church Missionary Society and World Christianity. 1799-1999. Grand Rapids: Wm B. Eerdmans Publishing.

Woodberry, Robert D. (2012). 'World Christianity. Its History, Spread, and Social Influence.' In Charles Farhadian, ed. Introducing World Christianity. Malden MA, Wiley and Blackwell: 259-271. 